\title{
MORRIS COHEN'S APPROACH TO LEGAL PHILOSOPHY
}

\author{
HAROID J. LASKr* \\ I
}

TN AN age of social confusion, it is not surprising that jurisprudence also should walk haltingly upon its way. Anyone who sought to find any single and central clue to the explanations of the legal process that are showered upon us would be embarking upon a well-nigh impossible task. It is not merely that the legal philosophies are so various. What makes the search so much more complicated is the fact that many of them are simply new names for very old things. What adds perhaps even more to the complexity is that few of the judges whose decisions we scrutinize in our effort to find the principles upon which they decide have ever had a constant and continuous philosophy, into the framework of which they sought to fit the cases they had to decide. High-sounding names not seldom conceal the fact that what the jurist has persuaded himself to regard as a new philosophy, or a new method, is in truth no more than a new terminological apparatus for an already outmoded set of concepts. If I may venture upon irreverence, I suspect that few people have done so much damage to legal philosophy as legal philosophers themselves. They have tortured it by trying to make it fit the fashion of the hour by analogy with physics, biology, psychology, engineering. They have twisted it by efforts at classification which have no other reality in the living material than the passion of the jurist to bring under the dominion of his art something that is only so brought by the deliberate rape of nature. What has, I suspect, done most damage of all is the effort to think of law and the lawmaker as something abstracted from life, and living a quasi-independent existence of its own; though, perhaps, it is almost rivalled in the harm it has wrought by the effort to bring the whole of the processes of law within the framework of some special metaphysics, whether it be that of Aquinas or Hobbes, of Kant or of Hegel.

It is not, I think, the least contribution that Professor Morris Cohen made to the jurisprudence of our time that he sought to insist upon three major things. The first was the vital part that logic must play in any rational account of its processes. Himself a rationalist in philosophic out-

* The London School of Economics and Political Science. 
look, no one fought more stoutly than he did for precise definition, for the effort to bring to that level of consciousness where reasoned analysis is possible the things that the lawmaker has done, or is seeking to do, with the power that is in his hands, and for the search behind what I may perhaps call the working rhetoric of the law to the purpose that rhetoric is seeking, not always knowingly or avowedly, to serve. I do not need to emphasize here either the width of his scholarship or the quality of the imaginative insight he brought to his juristic work. If he was not a system-maker, and if, as I think, his major contribution was to push out of the road a good deal of useless, and, not seldom, pretentious lumber that stood in the way of clear understanding, there is, after all, a great deal to be said for the man who makes a clearing in the jungle. In the long run, it is at least probable that the historian of legal philosophy, a half-century from now, will recognize that his negative contribution was of far more value than that of some of the more imposing attempts at juristic system-making which have seemed, as we watched them being constructed, like a great mountain in labor which, in the end, brought forth nothing more aweinspiring than the traditional mouse.

An admirable example of Professor Cohen's clear and incisive surgery is his well-known paper on the process of judicial legislation. ${ }^{x}$ Its virtue lies in its common sense and its directness. What he has done is simply to make it clear that the American constitutional system gives an authority to its judges, above all to the United States Supreme Court, beyond that which most other constitutional systems have been willing to entrust to their judiciaries. But what he brings out with striking clarity is that what Americans in general, and American lawyers in particular, tend to regard as a special merit in law-making need not be so regarded, and that the quality of the result depends upon the quality of mind and character of the judges who make that result. It is not a new analysis, though it is, I think, singularly happy in the examples by which its theme is illustrated. But no one who reads it is likely to urge thereafter that the source from which law emerges in the political constitution of a society is likely to give it some a priori title to be regarded as either more just or more objective because it comes from a court than when it comes either from a legislative body or from some government department clothed with the legal competence to make the law. I venture to suggest that a great deal of the fantastic nonsense which has been talked and written in the last forty years of administrative law as "star chamber justice," or the "new despotism," or "bureaucratic tyranny" would have remained unwritten or unspoken if

r Cohen, Law and the Social Order Ir2 (1933). 
those responsible for it had looked at the problems of modern government with the clear understanding that Professor Cohen displayed in this paper. Certainly I know nothing which would lead me to assume that the House of Lords is more likely than the Minister of Health to give the owner of a house all reasonable protection in an effort to prove that some local authority is wrong which deems it unsanitary; just as I have never been able to conceive why justice is more likely if the Supreme Court of the United States has the ultimate power to fix the rates for a commodity sold by a public utility than a body like the Interstate Commerce Commission or the Public Service Commission of the State of New York. ${ }^{3}$ Here, I think, Professor Cohen drove home with abounding skill the thing it appears so difficult to make lawyers understand-the fact that the procedure of the historic courts of law is not necessarily the socially best-fitted instrument to decide between different views of "reasonableness" in a rapidly changing society where, with but rare exceptions, it is the tendency of the judge to look backwards for his ratio decidendi, and even to make the canon of interpretation, when he has found it, the servant of a result he had deemed desirable even before he had begun to examine microscopically the details of the case. Certainly that seems to me largely true in most cases in which "public policy" is put forward as the ground for some decision. I refrain from citing American cases in illustration of this view. But anyone who is tempted to defend the findings of the House of Lords in the Taff Vale ${ }^{4}$ and Osborne cases, ${ }^{5}$ in one field, or in Roberts v. Hopwood ${ }^{6}$ in another, would, I believe, come to their examination with very different eyes if he set them in the clear perspective Professor Cohen so admirably drew.

The second example I take is one in which I was myself converted by Professor Cohen's power of logical analysis to see the error of my ways. The history of the long struggle to obtain recognition of the reality of corporate personality is well known. My generation was deeply influenced by learned jurists like Gierke ${ }^{7}$ and Maitland ${ }^{8}$ and Saleilles, ${ }^{9}$ as well as by

${ }^{2}$ Arlidge v. Local Government Board, [19I3] A.C. I20.

3 Cf. Frankfurter, The Public and Its Government (I93 $\mathrm{I}$ ).

4 Taff Vale Ry. v. Amalgamated Society of Railway Servants, [Igor] A.C. 426.

$s$ Osborne v. Amalgamated Society of Railway Servants, [rgro] A.C. 87 .

6 [1925] A.C. 578; cf. Laski, Studies in Law and Politics 202 (1932).

7 Gierke, Das Deutsche Genossenschaftsrecht (I868-xgr3).

${ }^{8}$ Maitland, translation of Gierke, Political Theories of the Middle Ages; see also 3 Maitland, Collected Papers (Igr $\mathrm{r}$ ).

9 Saleilles, De la personnalité juridique (rgro). 
political thinkers of the quality of J. N. Figgis, ${ }^{\text {xo }}$ to believe that when a body of men combine to promote an end upon which they are agreed that has the quality of longevity about it, they create a real person different in the rights and duties it bears from the elements which have gone to its making. I can still remember vividly the enthusiasm with which, as a young instructor some thirty years ago, I set out to prove this view in the pages of the Harvard Larw Review, ${ }^{\text {II }}$ the more enthusiastically because it seemed to me a powerful weapon in the hands of those who viewed, in any but a formal sense, the claim of the state to sovereignty as a dangerous threat alike to peace and freedom. There linger in my mind vivid memories of long arguments with Professor Cohen in which he sought to convince me that I was, in fact, taking a side which was bound to have reactionary results, in the ancient struggle between nominalism and realism, and that I should do better to follow the leadership of the great English medieval schoolman, William of Ockham, than to bathe in those waters of Lethe in which neo-Hegelian German jurists muddied the stream by their torrent of mysticism. For long, I was impressed, but unconvinced. But when I read Professor Cohen's remarkable paper on Communal Ghosts, ${ }^{12}$ I realised that $I$ had lain under a dangerous spell woven, above all, by the exquisite charm of Maitland-since Gibbon the greatest of our historians - and that bottomless pit of Gierke's learning which so easily overawes the young student who works his way, gasping, through its incredible pages for the first time. Looking back, I can see that Professor Cohen's paper was, for me, at least, an intellectual emancipation of no mean importance. I should like to explain why this was so, since the experience I owed to him then may well be an experience of which other students stand in need in generations later than my own.

The first lesson it taught me-perhaps the most important-was not to take learning as such as a probable index to wisdom; it may indeed prove an impediment to the attainment of creative understanding. I venture the judgment that this has been particularly true in the case of Otto von Gierke's massive work. As one looks back upon it, the unstated assumption upon which it was built was a relic of that German romantic nationalism, which, like the work of Adam Müller and Fichte, was an attempt to revive the German spirit after the catastrophes of the Napoleonic wars. Gierke sought to create the foundations of a German jurisprudence which should be as free as possible from what he regarded as the taint of

${ }^{10}$ Figgis, Churches in the Modern State (IgIr).

II Laski, The Personality of Associations, 29 Harv. L. Rev. 404 (I9I6).

${ }^{22}$ Reprinted in Cohen, Reason and Nature (I93I). 
foreign movements, which began to exercise their special impact after the Reception in the sixteenth century. By restoring the true German $\mathrm{Ge}$ nossenschaftsrecht he was asserting the superiority of its principles over foreign importations which were a hindrance to the full expression of the genuine German spirit.

That, as Professor Cohen saw, was the basic principle upon which all Gierke's work rested. It not only explains the fantastic disproportion of the judgments made in his well-known book on Althusius; ${ }^{.3}$ it also explains the striking errors and omissions in the fourth volume of his Deutsche Genossenschaftsrecht, where the primacy of German influence on political thought is established by the curious elevation of the significance of wholly forgotten, and rarely important, German jurists of the seventeenth and eighteenth centuries, and the neglect, or the omission, to discuss the importance of far more important writers in England, France, and the American colonies. The affirmation that corporate personality was real, which led, in Gierke's argument, to the exaltation of the statepersonality above all others in typical Hegelian fashion, was, as Cohen saw, not only built upon a metaphor which was itself an illogical analogy, but was also a means to the diminution of man's individuality by making him important only in the combat of the relations in which he was involved. At bottom, it was an attempt to revive the feudal view of the citizen's place in society, by maintaining a theory of society composed essentially of corporate groups which could attain the necessary unity only by accepting the subordination of the area over which they had authority to the sovereign power of the state.

It is easy to see the attraction of this view for Maitland, not only the supreme historian of medieval law, but also as a good Victorian radical, profoundly opposed to the way in which the stern judicial dogmatists, like Bramwell in England, or Field, J., in the United States, regarded the doctrine of ultra vires as a method by which laissez faire theory could set limits to the intervention of government in business affairs. Figgis, who was deeply influenced by Maitland, was passionately concerned to free the Church of England from dependence upon the state-power, a dependence emphasized, shortly after he began his work, by the decision of the House of Lords in the famous Free Church of Scotland ${ }^{\mathrm{x} 4}$ case. For that decision revealed that even when a church had ceased, by deliberate choice, to be an established church supported by the state-power, the fact that its

${ }^{2}$ Gierke, Johannes Althusius und die Entwicklung der naturrechtlichen Staatstheorien (I880).

${ }^{14}$ Free Church of Scotland v. Overtoun, [I9O4] A.C. 5I5; for a full account see Orr, The Free Church of Scotland Appeals (1904). 
property was vested by deed in a body of trustees meant that, when questions involving property arose, the secular courts possessed the right to determine whether religious changes in the habit of the church were ultra vires or no; if this were accepted, all churches, voluntary or established, were necessarily, in final analysis, the creatures of the state-power. And Figgis, as I know, was led to still more enthusiasm for the doctrine that corporate personality was real when, in Thompson $v$. Dibdin, ${ }^{15}$ a King's Bench judge could insist that if, as the Church of England argued, the canon law was the law of God, nevertheless that law could be altered at will by Act of Parliament. I myself was mainly influenced by the series of English decisions, from the first Taff Vale case in Igor, ${ }^{16}$ to the final Osborne judgment in I9I0, ${ }^{{ }^{7}}$ by the realization that British judges used either the canons of statutory interpretation, or, alternatively, the doctrine of public policy, to limit the activity of British trade unions to a sphere which their private social philosophies thought fitting and proper.

When Professor Cohen insisted that the corporate person was a "communal ghost," he cleared the ground, I think, for a clearer understanding of social organizations, as well as for a deeper insight into the functions of law. A group of human beings is not a person, in the sense that each member of the group is a person. It is only by metaphor that we say "it" acts, that "it" has this opinion or that, that "it" has a reputation which can be damaged, or that "it" concludes agreements or commits torts. For whenever, in fact, we wish to deal with "it," the corporate person, it is with one of its members with whom we deal. "Its" voice is communicated to us by his voice; "its" will is made known to us by a decision that he announces. The corporate "person," in short, is not a person over and above its members. It is an idea which unites them in a relation and causes them, by their acceptance of the purpose implicit in the idea, to organize themselves for action which makes for the fulfilment of the purpose. Apart from them, there is no action. The will that operates finds the unity it has in the organized unity of their wills. When we say that the National Association of Manufacturers "has said" this, or "has published" that, we mean that a man, or a committee of men, authorized by the terms of a constitution to speak in the name of all who have united to support a certain body of principles, have, on their behalf, given expression, in some way, to their views. When we say that it is the view of the Roman Catholic Church that the Pope, speaking ex cathedra, is infallible, we mean that the mem-

\footnotetext{
${ }_{15}[$ rgra $]$ A.C. 533.

${ }^{16}$ Taff Vale Ry.v. Amalgamated Society of Railway Servants, [rgor] A.C. 426.

17 Osborne v. Amalgamated Society of Railway Servants, [xgro] A.C. 87 .
} 
bers of this church will accept the views of the Pope as binding upon them in those areas of belief or conduct in which the Vatican Council of I470 decided by decree that he was infallible. The activities of the American Bar Association are only "its" activities in the sense that its members have agreed to certain procedures whereby, within fairly well-defined limits, its officers and agents may act on their behalf. "It" is not itself a person; "it" is a purpose willed by the relations between human beings, who have organized themselves so to act that their purpose may be fulfilled.

I do not think the importance of this approach can be exaggerated. It makes us see, what it is imperative that we should see, that behind all collective entities, however vast, however ancient, however precious they may be regarded by their members, are always individual men and women, and that it is the will of each of these that lends to the collective "person" whatever strength "it" has. All of us are free in a community to give or to withhold our consent to action that is taken in our name by some organization of which we are a part. That is true, it is worth while adding, of men and women in their capacity as citizens to whom some order comes which the government of the community is able to impose by its possession of the state-power. The authority of any law-enforcing group is a function of its power; and its power depends upon the support upon which it can count in any given situation by which it is confronted. When Bismarck waged the Kultur-Kampf against the Roman Catholic Church in the seventies of last century, what he in fact fought was a body of men and women, professing the Roman Catholic faith, who preferred to suffer the penalties he was prepared to impose rather than give up the outlook which, as Roman Catholics, they found acceptable. In the end it was Bismarck who had to give way, because those whom he sought to compel to acceptance of his orders paid the penalties he felt able to exact rather than. give way. I agree with the view Professor Cohen so strongly held that only by a continuous emphasis that men and women alone are persons can we make responsibility real in the relations of community life. As soon as we personify the idea, whether it is a country or a church, a trade union or an employers' association, we obscure individual responsibility by transferring emotional loyalties to a fictitious creation which then acts upon us psychologically as an obstruction, especially in times of crisis, to the critical exercise of a reasoned judgment. We then tend to abdicate before that duty to judge the validity of the rules we are called upon to obey which is, in fact, the very essence of good citizenship. For law is good not by reason of the source from which it emanates but by reason of the 
consequences it seeks to secure, as seen in terms of the methods by which it attempts to secure those consequences. It presents itself to us as something about which we have to make up our minds; and we create conditions in which, psychologically, we have yielded any mind we have if we assume that either consequence or method is sought or attained on behalf of a person who is separate from, still more, over and above, each one of our individual selves. The danger of the doctrine that corporate personality is real is the danger that we give our consciences into the keeping of some national government, some church, or some other association and that their operation is then organized from without until we fail to realise that we have become nothing more than an automatic instrument in the hands of men into the validity of whose power it never occurs to us to enquire.

\section{II}

This, I believe, is one of the outstanding principles of Professor Cohen's work in jurisprudence. It is the insistence that all power is exercised by some men over other men. Power has no right as such; it has to acquire right both by what it does and by the manner of its doing it; moreover, in any given society, it is by the assent of each of its members that it acquires it. It is this emphasis which gives its special significance to Professor Cohen's definition of the field with which law is concerned. "The subject matter of the law," he wrote, "is the regulation of the conduct of individuals living in those more or less permanent relations we call society. ${ }^{\prime 38} \mathrm{He}$ meant, thereby, I think, two things. First, he sought to convey his view that the work of the law lies increasingly in the field of conscious control, and, second, that the objectives this control seeks to obtain must be increasingly capable of rational justification. That is why he would not admit that a court could justifiably derive its jurisdiction by some law beyond, or behind, the statute by which its authority is determined. "To be ruled by a judge," he wrote, "is to the extent that he is not bound by law, tyranny or despotism. It may often be intelligent and benevolent, but it is tyranny just the same." It is almost the identical view that Montesquieu had taken nearly two centuries before. ${ }^{20}$

This led him into conflict with two schools of thought in jurisprudence which have had considerable influence in recent years. It made him suspicious of that doctrine of "free interpretation," of which Ehrlich in Aus-

${ }^{18}$ Cohen, Law and the Social Order 173 (1933).

${ }^{x 9}$ Cohen, Positivism and the Limits of Idealism in the Law, 27 Col. I. Rev. 237 (1927).

${ }^{20}$ Montesquieu, Esprit des lois, Book VI, Ch. VI. 
tria ${ }^{2 x}$ and Gêny in France, ${ }^{22}$ have been, perhaps, the most notable recent representatives. For that is to say, in the end, that, subject only to statute or constitutional amendment, the law is to be what the courts think best for the country in which they have jurisdiction. This comes very close to Chief Justice Hughes' famous phrase that the "constitution is what the judges say it is." Professor Cohen thought this dangerous doctrine. It created the presumption, in the first place, that any existing social situation is legal, presumptively at least, by the fact of its existence, and that, in general, the burden of proof to the contrary lies upon those who ask the courts to differentiate between them. He was too well aware that judges, generally, have been on the side of the past, and are as willing as most other human beings to give to custom, especially to long-standing custom, the force of law. "Human inertia and imitativeness," he wrote, "give custom itself a regulative and normative force, compelling uniformity where the individual might otherwise diverge from the common way." ${ }^{23}$ I do not mean to imply that he had a special reverence for the principle of stare decisis. In one of the last letters I had from him, in I940, he drew my attention to what he called "the admirable remarks [of Justice Frankfurter] in Bryant v. Helvering ${ }^{24}$ - a gentler re-phrasing of Holmes' great dictum that 'it is revolting to have no better reason for a rule of law than that it was laid down in the time of Henry IV. It is still more revolting if the grounds upon which it was laid down have vanished long since, and the rule simply persists from blind imitation of the past.' "'25 But he felt intensely the danger to any society where there is deliberate self-enlargement of judicial discretion. He accepted the inevitability of judicial legislation; but he was strongly hostile to any effort on the part of the courts to use their powers to regulate men's behavior according to their own notions of what was best for the community. He thought there was no swifter way of bringing the judiciary into disrespect, and thereby destroying that respect for the idea of law which is one of the main safeguards of social order.

He disliked, therefore, the theory that the judge is to act as though, for all practical purposes, he were a third chamber of the legislature, and, wherever necessary, the guardian of a higher law than anything it was in the power of the elected members of a legislature to make. But even more,

2x Ehrlich, Fundamental Principles of the Sociology of Law (x936).

${ }^{22} 2$ Gény, Méthode d'interprétation et sources en droit privé positif 180 (rgrg).

${ }^{23}$ Cohen, Law and the Social Order 206 (1933).

24309 U.S. I06 (r939).

${ }^{25}$ Hoimes, Collected Papers I87 (I920). 
I think, he disliked the approach to law of which men like Jerome Frank and Thurman Arnold are perhaps the most effective representatives. $\mathrm{He}$ regarded their work not only as an index to the general intellectual confusion of our time, but even beyond that, likely to diminish the effort of law to attain general truths by the process of rational discussion. Logical consistency had as much place, for him, in the making of judicial decisions as attempts to psychoanalyze the judge's personality, or, rather in the manner of Mr. Peeker in Pickwick Papers, to suspect that if one knew what he ate for breakfast on the morning of the trial, one might fruitfully speculate upon the probable character of his recommendations to the jury. He had a genuine, and, I believe, a wholesome, fear of the growth of antiintellectualist philosophies of law, which regarded law merely, in the fashion of Georges Sorel, as successful myths intended by the successful to persuade or coerce the defeated into acceptance of their defeat. He was insistent, as his well-known paper on the revival of natural law ${ }^{26}$ makes evident, that a law which is consciously separated from justice will sooner or later cease to command respect. For him there existed fundamental ethical principles, of which the need for freedom of discussion was perhaps the most important, that law must always seek to protect lest, by their erosion, it assists in encompassing its own destruction. He agreed that the application of these fundamental ethical principles to concrete situations must be elastic; they were to be treated as hypotheses which were always subject to some modification in the light of the facts they encountered and not as theological dogmas. What he regarded as dangerous was the attempt to make the foundations of law no more than pragmatic evaluation by those in a position to operate its machinery of what would suit them best. The answer, he once remarked to me, to the lawyers who think that legal rules are like the bottles of colored water that the doctor gives to the ignorant but importunate patient, is that if the patient be really ill, the medicine will not cure him, and he will cease to believe in the doctor.

I venture to suggest that there is an important sense in which Professor Cohen was right in this view, and that most anti-intellectualist theories of law, even when they are as brilliantly stated as those of Judge Thurman Arnold, have an atmosphere about them which, when closely examined, shows that they foreshadow the coming breakdown of a traditional system of values in the society where they obtain a hold. The argument that, as Thurman Arnold put it, "principles have been obstacles and not aids" plays, as Morris Cohen saw, right into the hands of the reactionaries. For

${ }^{26}$ Reprinted in Cohen, Law and the Social Order (r933). 
its first effect is to create the suspicion that all truth is, in fact, subjective -a view which can easily be shown to result in the unhappy doctrine that we must always expect might to be right. For this hostility to principle leaves us with no real choice except anarchism, on the one side, and effciency, on the other. It is obvious that the necessity for security as the basis of an ordered, and indeed a rational, life will always result in the men who can maintain order becoming the masters of any society in which the only alternative is the refusal to accept any guiding rules, just because they are rules which attempt to guide. And it is worthwhile here to repeat his continuous insistence that laws in the social sciences only differ from laws in the natural sciences in that they are immensely more difficult to discover and far more likely to be limited by personal bias of which the maker is himself wholly unaware: The realists have written about the contrast between law-making and natural laws in physics or chemistry as though the physicist or the chemist were free from personal bias. That is, of course, a wholly mistaken view of the history of science; and, once it is accepted, it leads to exactly that distrust of reason which is one of the graver manifestations of the confusion of our times, a confusion, I venture to add, which is nowhere more fully exhibited than in the developments of jurisprudence in the last thirty or forty years.

I add that, just because every observer has his personal bias, of which he may be unconscious, I think that Professor Cohen had his own, and that this made him do less than justice to that economic interpretation of jurisprudence which is. one of the major contributions of Marxism to the understanding of law. He accepted, he wrote, the main findings about the American constitution which were set out in the famous book of Professor Charles Beard. But he then goes on to say that the economic interpretation is "too simple in not assigning sufficient importance to intellectual and sentimental factors, and it does not go far enough on the economic side, in its inadequate appreciation of the role of the farmer as the small property-owner in the development of the American ideology."27 To this he adds that "those who talk of the capitalist class as the absolute rulers of this country are the victims of a mythology," and that "the rural mentality of a sparsely populated country gerrymandered by a farming majority even in industrial states, was able to dominate the American judiciary until the end of the nineteenth century."28

Anyone who examines Professor Cohen's assessment of communism ${ }^{29}$ will, I suggest, feel confident that he seriously underestimated the impor${ }^{27}$ Cohen, The Faith of a Liberal 186 (I946).

${ }^{28} \mathrm{Mbid}$.

29 Ibid., at Irg. 
tance of a Marxian analysis of law. It is not, indeed, unfair to suggest that his rejection of it was largely the outcome of a failure to understand it in its essentials. There lurked behind the whole of his approach too deep a distrust of violence, too sensitive a consciousness of the price men pay for revolution, for him to approach any Marxian jurisprudence objectively. No one can examine trials like those of the Chicago "anarchists," of Mooney and Billings, of Sacco and Vanzetti, without having to admit that they show on the part of judges and juries a class-attitude entirely in accord with the Marxist canon. So, too, does the major part of the decisions in American courts relating to freedom of speech. So, once more, does the major part of the law relating to trade-union practices. Most of the objections Professor Cohen raises are, in fact, not arguments against a Marxian theory of law at all, but an argument against its ignorant application. The fundamental fact is that the state-power in the United States, and the judiciary as an instrument of that state-power, does not differ, except in the degree of its habits, from the character of the state-power in any other society. There, as elsewhere, it is the supreme coercive instrument which is used to protect the relations of production from invasion by those who seek to change them. When Professor Cohen argues that the economic interpretation fails to "assign sufficient importance to intellectual and sentimental factors," he has made an inadmissible separation between the economic factors and the intellectual outcome of the different relations to which, granted some given mode of production, they give rise. When he speaks of the role of the small property-owner and the farmer in the development of American ideology, he forgets the really vital fact that, since the Civil War, they have had constantly to give ground before the massive power of concentrated wealth, and that, in general, they have influenced the margins rather than the centre, both of the judicial and the legislative mind. Populist movements in the United States have been impressive, but they have never been really successful for more than a very brief period, and over a relatively small area. The major influence of the small property-owner upon the legislatures and the courts has been a more generous law of bankruptcy, and a more generous interpretation of its application, than is common in the legal systems of Europe. But it is a serious anachronism to suggest that anything has really hindered, generally since 1865 and particularly since 1900 , the authority of concentrated bigness in economic life to determine the categories of law. On this matter, the failure of the Sherman Act and the skill with which corporation lawyers have persuaded the courts to give to administrative law what may not unfairly be termed a second-class status are alone sufficient 
proof. That Professor Cohen failed to weigh these things is curious in a philosopher of his remarkable penetration.

But I suspect that his hostility to a Marxist view of law was born, above all, of an unwillingness to admit that any social problem was ultimately insoluble in terms of reason. Here Cohen's passion for logic combined with his childhood memories of Czarist Russia to make almost unbearable to him the idea that there are social antitheses too profound to be bridged by discussion. His own power to see round a question, his conviction that men of good will could always reach a fair-minded compromise, his anxiety to do justice to the point of view of those with whom he disagreed; all these were among the most characteristic of his traits. It made him, I think, at once overestimate the degree to which they exist in other people, as it made him underestimate the degree to which modes of production shape the climate of ideas by which men are moved independently of their own conscious will. It is no more a disproof of the general Marxist philosophy that Marx and Engels were not proletarian by origin than it is proof of its validity that its strength has mainly come from the support of working-class organizations the members of which were taught far more by events in which they were involved than by conscious devotion to a highly technical body of doctrine. Morris Cohen lived in one of those difficult epochs in which, as in the Wars of Religion in the sixteenth and seventeenth centuries, interests clothed themselves in the symbolism of creeds that they might acquire greater strength by appealing to the subconscious emotions of men. He made it his major function, in the field of legal philosophy, to arrest the drift to irrationalism by making the symbols clear by the rigorous process of logical scrutiny. He rendered, I submit, high service by giving to a realist jurisprudence the weapons it requires in the unending battle with idealist interpretation. The method he used was more important than the results he attained. But the method he used has the immense importance of enabling us to consolidate the positions gained by its application. The life of the law may have been shaped by experience rather than by logic. But it was a contribution of great value to see, as Morris Cohen saw, that only the logical analysis of experience can make men able consciously to shape their own destiny. 